\title{
Infectious keratitis after pterygium surgery
}

\author{
Mohammad Soleimani $\mathbb{1}^{1} \cdot$ Seyed Ali Tabatabaei ${ }^{1} \cdot$ Mohammad Mehrpour $^{1} \cdot$ Mirataollah Salabati $^{1}$. \\ Razieh Mahmoudzadeh ${ }^{1}$
}

Received: 17 February 2019 / Revised: 24 August 2019 / Accepted: 6 October 2019 / Published online: 24 October 2019

(c) The Royal College of Ophthalmologists 2019

Surgical excision is the only definitive treatment for pterygium. Pterygium removal is usually combined with a conjunctival autograft and/or antimitotic molecules to reduce the rate of recurrence [1]. Reported complications include keratitis, scleral ulceration, necrotizing scleritis, perforation, iridocyclitis, cataract formation, glaucoma, and scleral calcification [2,3]. In this study, we described eleven cases of infectious keratitis following pterygium surgery. The authors are unaware of any other studies detailing keratitis after pterygium surgery.

In this retrospective study, the medical records of eleven patients who presented with infectious keratitis following pterygium surgery from January 2016 up to December 2017 were reviewed. The patient data recorded at other hospitals were collected by reviewing hospital records. The data of the patients who underwent surgery at Farabi Eye Hospital and were followed using the routine schedule were extracted from hospital records and the patients were advised about any untoward post-operative events. Cases with apparent infiltration in the cornea were included, but patients with corneal thinning without infiltration such as dellen formation were excluded from the study. The principles of the Declaration of Helsinki were observed and the study was approved by the local ethics committee.

Eight patients were men. The mean age of the patients was $63.6 \pm 8.2(53-77)$ years. The mean latency period between pterygium surgery and corneal ulcer was $49.3 \pm$ 41.2 (25-165) days. Five cases developed keratitis as a result of surgery at Farabi Eye Hospital out of a total of 2118 pterygium operations during the same time period, suggesting an incidence rate of two corneal ulcers in every 1000 pterygium operations. However, it is possible that

Mohammad Soleimani

Soleimani_md@yahoo.com

1 Ocular Trauma and Emergency Department, Farabi Eye Hospital, Tehran University of Medical Sciences, Tehran, Iran some patients with keratitis following pterygium surgery at Farabi Eye Hospital were visited elsewhere.

The site of pterygium was nasal in ten cases and temporal in one case. Intraoperative topical mitomycin-C (MMC) $(0.2 \mathrm{mg} / \mathrm{ml}$ for $2-3 \mathrm{~min})$ was administered in all cases with no postoperative topical MMC drops. Most of the cultures (five patients) demonstrated gram-positive bacteria. (Table 1). Corneal thinning was seen in eight patients of whom two presented with a corneal perforation (Fig. 1a, b). A tectonic surgical support was used in five patients with corneal thinning including amniotic membrane transplant (AMT), cyanoacrylate glue, patch graft (using the anterior stroma following endothelial keratoplasty), and penetrating keratoplasty. Five cases presented with sclerokeratitis and scleral thinning in whom a tectonic procedure was undertaken (Table 1). A history of herpetic keratitis was negative in all patients. The corneal sensation was intact in all patients on pre-operative examination.

There are case reports of microbial keratitis following pterygium surgery. Shenoy et al. reported a case of late corneal thinning and keratitis after pterygium surgery. They considered the use of MMC as a primary risk factor by causing delayed wound healing in response to keratocyte depletion; however, they did not report any microorganisms [4]. Because intraoperative MMC was used in all of our cases, their conclusion could be consistent with our study. Hirst reported only one case of infectious keratitis in 1000 pterygium operations. All operations were done by one surgeon [2]. In our study, the incidence of keratitis was two cases in 1000 pterygium operations. It may be related to the fact that operations in our hospital were performed by residents.

Excessive scraping, cauterization, and adjunctive antiproliferative treatment such as beta-irradiation and mitomycin $\mathrm{C}$ were described as significant risk factors for infectious sclerokeratitis in previous studies [3-6]. Corneal epithelial defects following surgery and a chronic avascular zone in the area of the pterygium surgery would predispose the patients to infection [1]. (Fig. 1c) Corneal ulceration and 
Table 1 Descriptive data of patients with post pterygium keratitis

\begin{tabular}{|c|c|c|c|c|c|c|c|c|c|c|c|c|c|}
\hline Case & $\begin{array}{l}\text { Age } \\
\text { (years) }\end{array}$ & Gender & $\begin{array}{l}\text { Site of } \\
\text { pterygium }\end{array}$ & Technique & Complication & $\begin{array}{l}\text { Latency period between } \\
\text { pterygium surgery and } \\
\text { keratitis (Days) }\end{array}$ & $\begin{array}{l}\text { Corneal } \\
\text { thinning }\end{array}$ & Scleritis & Surgery & $\begin{array}{l}\text { Topical medical } \\
\text { treatment }\end{array}$ & Culture & BCL & $\begin{array}{l}\text { Systemic } \\
\text { disease }\end{array}$ \\
\hline 1 & 56 & Female & Nasal & AMT & - & 27 & + & + & $\begin{array}{l}\text { Patch graft } \\
\text { then PKP }\end{array}$ & $\begin{array}{l}\text { ceftazidime, } \\
\text { vancomycin }\end{array}$ & $\begin{array}{l}\text { Streptococcus } \\
\text { pseudomonas }\end{array}$ & + & DM \\
\hline 2 & 65 & Male & Nasal & AMT & - & 75 & + & - & - & $\begin{array}{l}\text { ceftazidime, } \\
\text { vancomycin } \\
\text { changing to } \\
\text { levofloxacin }\end{array}$ & - & - & - \\
\hline 3 & 74 & Male & Nasal & Conjunctival graft & $\begin{array}{l}\text { Bare sclera, } \\
\text { conjunctival } \\
\text { retraction }\end{array}$ & 165 & - & + & $\begin{array}{l}\text { Scleral } \\
\text { debridement and } \\
\text { conjunctival flap }\end{array}$ & $\begin{array}{l}\text { ceftazidime, } \\
\text { amikacin then } \\
\text { changed to } \\
\text { amikacin }\end{array}$ & Pseudomonas & - & - \\
\hline 4 & 62 & Male & Nasal & Conjunctival graft & & 32 & + & + & AMT & cefazolin, amikacin & - & - & - \\
\hline 5 & 60 & Male & Nasal & AMT & & 35 & + & + & PKP & cefazolin, amikacin & Streptococcus & - & - \\
\hline 6 & 53 & Male & Temporal & $\begin{array}{l}\text { Second surgery } \\
\text { for the recurrence } \\
\text { by } \\
\text { conjunctival graft }\end{array}$ & & 55 & - & - & - & cefazolin, amikacin & $\begin{array}{l}\text { Staphylococcus } \\
\text { epidermis }\end{array}$ & - & - \\
\hline 7 & 77 & Male & Nasal & AMT & & 25 & + & - & Glue & cefazolin, amikacin & - & - & - \\
\hline 8 & 57 & Male & Nasal & Conjunctival graft & $\begin{array}{l}\text { Bare sclera, } \\
\text { retracted } \\
\text { conjunctiva }\end{array}$ & 28 & + & - & - & cefazolin, amikacin & - & - & - \\
\hline 9 & 62 & Female & Nasal & Conjunctival graft & $\begin{array}{l}\text { Conjunctival } \\
\text { retraction }\end{array}$ & 32 & + & + & PKP & Voriconazole & Fusarium & - & - \\
\hline 10 & 59 & Female & Nasal & AMT & - & 27 & + & - & - & $\begin{array}{l}\text { Fortified cefazolin } \\
\text { and amikacin then } \\
\text { changed to fortified } \\
\text { cefazolin }\end{array}$ & Staphylococcus aureus & - & - \\
\hline 11 & 75 & Male & Nasal & $\begin{array}{l}\text { Conjunctival } \\
\text { rotational graft }\end{array}$ & - & 42 & - & - & - & $\begin{array}{l}\text { Fortified cefazolin } \\
\text { and amikacin then } \\
\text { changed to fortified } \\
\text { cefazolin }\end{array}$ & Pneumococcus & - & - \\
\hline
\end{tabular}

$B C L$ bandage contact lens, $P K P$ penetrating keratoplasty, $A M T$ amniotic membrane transplantation, Glue cyanoacrylate glue, $D M$ diabetes mellitus

Fig. 1 Panel a shows perforated keratitis one month after pterygium surgery and amniotic membrane transplantation. Panel b shows another patient with perforated keratitis after pterygium surgery and conjunctival graft. Panel c shows keratitis with conjunctival retraction and bare sclera after pterygium surgery and conjunctival graft, as mentioned in the text, long-term scleral and anterior segment ischemia could result in keratitis a
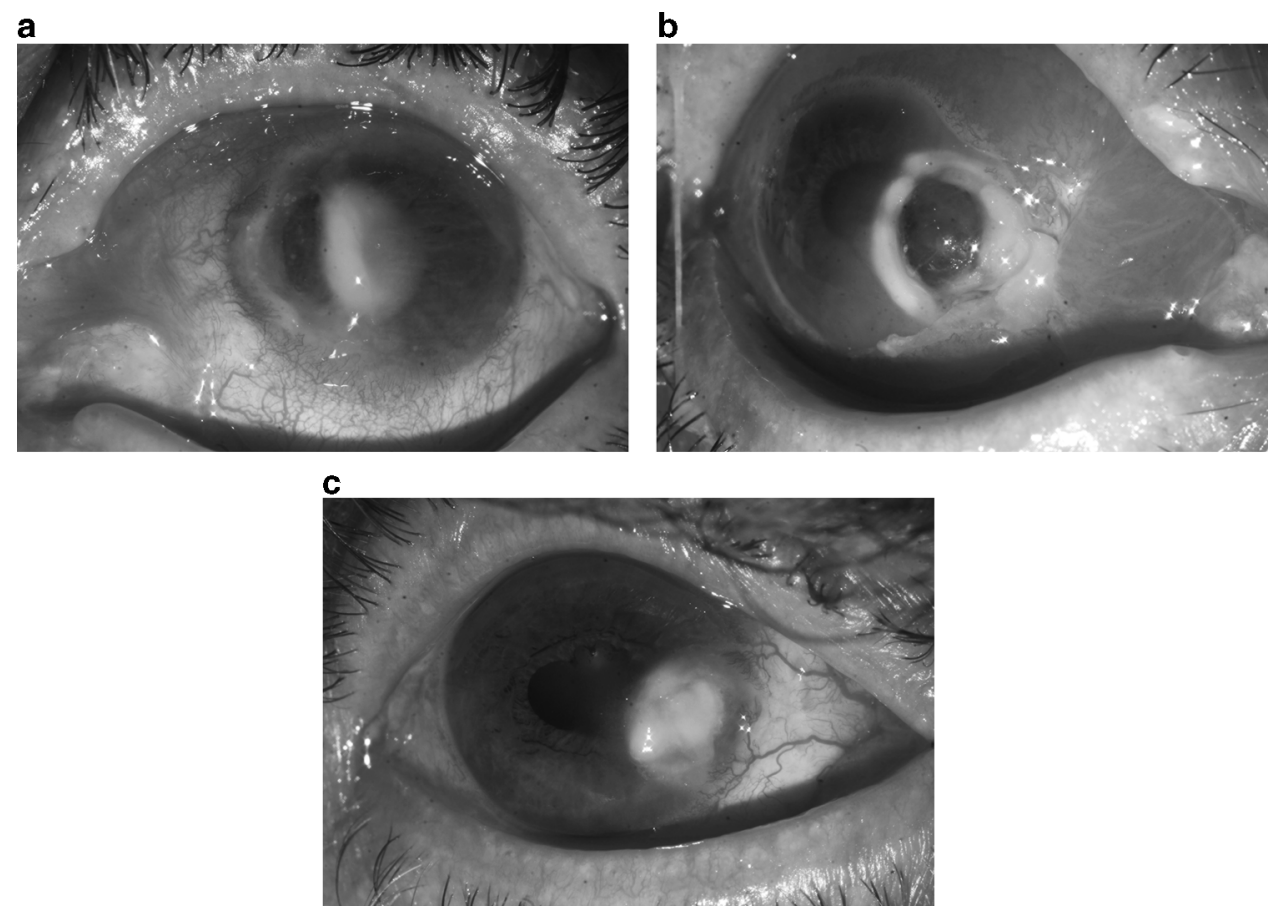

perforation in Sjogren syndrome [6] may follow pterygium excision. In our study, only one case (Case 8 in Table 1) presented with dry eye syndrome documented by a tear breakup time (TBUT) less than $6 \mathrm{~mm}$ in both eyes compatible with a diagnosis of dry eye.
The latency period between pterygium surgery and sclerokeratitis was 10 days to 18 years in the previous studies [7]. This latency period was 1 to 6 months in our study. In the previous studies, Pseudomonas aeruginosa was the most common microorganism causing scleritis after 
pterygium surgery [3]. In our study, gram-positive microorganisms were cultured more frequently compared to other organisms, which may be related to the inclusion of the keratitis vs. scleritis after pterygium surgery in our study. Although surgical site infection is expected to occur in early postoperative days, scleritis and keratitis may develop more than one month after the primary surgery. Some authors propose that MMC could cause necrotizing scleritis and the subsequent ischemic area of the anterior segment could lead to superinfection by different microorganisms. In our study, the cornea was involved in all cases, and the sclera was involved in five cases. One of the limitations of this study was its retrospective nature, and another limitation was the different experience levels of surgeons in pterygium surgery.

In conclusion, keratitis could unexpectedly occur more than one month after pterygium surgery; therefore, close follow-up of susceptible patients for a more extended time is warranted. Gram-positive organisms were most frequently isolated. This finding could emphasize the possible role of ocular surface flora superinfection, especially with grampositive bacteria, in the context of segmental scleral ischemia following the use of topical steroid in the presence of persistent epithelial defects. This study found an incidence of $2 /$ 1000 for microbial keratitis after pterygium surgery. A prospective study would be required to substantiate our findings.

\section{Compliance with ethical standards}

Conflict of interest The authors declare that they have no conflict of interest.

Publisher's note Springer Nature remains neutral with regard to jurisdictional claims in published maps and institutional affiliations.

\section{References}

1. Kaufman SC, Jacobs DS, Lee WB, Deng SX, Rosenblatt MI, Shtein RM. Options and adjuvants in surgery for pterygium: a report by the American Academy of Ophthalmology. Ophthalmology. 2013;120:201-8.

2. Hirst LW. Recurrence and complications after 1,000 surgeries using pterygium extended removal followed by extended conjunctival transplant. Ophthalmology. 2012;119:2205-10.

3. Rubinfeld RS, Pfister RR, Stein RM, Foster CS, Martin NF, Stoleru $\mathrm{S}$, et al. Serious complications of topical mitomycin-C after pterygium surgery. Ophthalmology. 1992;99:164.

4. Shenoy R, Bialasiewicz AA, Al-Barwani B. Late corneal thinning and keratitis following mitomycin-C use in pterygium surgery. Sultan Qaboos Univ Med J. 2011;11:286-7.

5. Tarr KH, Constable IJ. Late complications of pterygium treatment. Br J Ophthalmol. 1980;64:496-505.

6. Pfister RR, Murphy GE. Corneal ulceration and perforation associated with Sjögren's syndrome. Arch Ophthalmol. 1980;98:89-94.

7. Huang SC, Lai HC, Lai IC. The treatment of Pseudomonas keratoscleritis after pterygium excision. Cornea. 1999;18:608-11. 